\title{
Inequality in Health Services for Internal Migrants in China: A National Cross-Sectional Study on the Role of Fund Location of Social Health Insurance
}

\author{
Qiang Yao ${ }^{1,2,3} \mathbb{1}$, Chaojie Liu ${ }^{2, *} \mathbb{C}$ and Ju Sun ${ }^{1,3, *}$ \\ 1 School of Political Science and Public Administration, Wuhan University, Wuhan 430072, China; \\ yaoqiang@whu.edu.cn \\ 2 School of Psychology and Public Health, La Trobe University, Melbourne 3086, Australia \\ 3 Institute of Health, Wuhan University, Wuhan 430071, China \\ * Correspondence: c.liu@latrobe.edu.au (C.L.); sunju@whu.edu.cn (J.S.)
}

Received: 12 July 2020; Accepted: 28 August 2020; Published: 31 August 2020

\begin{abstract}
On-the-spot settlements of medical bills for internal migrants enrolled with a social health insurance program outside of their residential location have been encouraged by the Chinese government, with the intention to improve equality in healthcare services. This study compared the use of health services between the internal migrants who had local health insurance coverage and those who did not. Data $(n=144,956)$ were obtained from the 2017 China Migrants Dynamic Survey. Use of health services was assessed by two indicators: visits to physicians when needed and registration (shown as health records) for essential public health services. Multi-level logistic regression models were established to estimate the effect size of fund location on the use of health services after controlling for variations in other variables. The respondents who enrolled with a social health insurance scheme locally were more likely to visit physicians when needed (adjusted odds ratio $(\mathrm{AOR})=1.18,95 \% \mathrm{CI}=1.06-1.30)$ and to have a health record $(\mathrm{AOR}=1.47,95 \% \mathrm{CI}=1.30-1.65)$ compared with those who enrolled outside of their residential location: a gap of 3.5 percentage points (95\% CI: $1.3 \%-5.8 \%$ ) and 6.1 percentage point (95\% CI: $4.3 \%-7.8 \%$ ), respectively. The gaps were larger in the rural-to-urban migrants than those in the urban-to-urban migrants (AOR $=1.17,95 \%$ $\mathrm{CI}=0.93-1.48$ for visiting physicians when needed; AOR $=0.71,95 \% \mathrm{CI}=0.54-0.93$ for having a health record). The on-the-spot medical bill settlement system has yet to fully achieve its proposed potential as inequalities in both medical and public health services remain between the internal migrants with and without local health insurance coverage. Further studies are needed to investigate how on-the-spot settlements of medical bills are implemented through coordination across multiple insurance funds.
\end{abstract}

Keywords: health inequalities; migrants; social health insurance; China

\section{Introduction}

The term "internal migrants" refers to people who move to and live in a place outside of their registered residency as defined by the household registration system (also known as "Hukou") in China [1,2]. Hukou was created in late 1950s in line with where a person was born [3,4]. In the early stage (1950s-1980s), it was designed to restrict population mobility, serving as an important infrastructure for resource allocations under the planned economy [3,5], especially for the dual (urban vs rural) social welfare systems [6]. For example, rural people were assigned with local farming lands and not allowed to be employed in an urban setting [4]. Meanwhile, public and social services such as job opportunities, housing allowance, educational opportunities, healthcare services, social insurance 
and other welfare entitlements were always linked to Hukou managed by local governments. Moving to a place without Hukou meant loss of all of the entitlements [1,7-10].

Since China adopted the market economic reform in the 1980s, the Hukou system has evolved to accommodate the increasing demand for urban workforces [3,4]. The attitudes of the Chinese government toward internal population mobility have shifted from "restriction" to "encouragement and assistance" [7,11]. People no longer worried about their subsistence needs without a Hukou $[4,7]$. As a result, a large number of rural workforces were freed up and started to seek jobs outside their Hukou location. The rapid industrialization, in particular in the eastern coastal region, attracted large scales of population internal migration [12]. The population of internal migrants increased from about 6 million in the 1980s to 244 million in 2017, accounting for about $18 \%$ of the population size nowadays in China [13,14]. The majority of internal migrants occupied job positions that would not otherwise be filled by the locals [15], making a great contribution to the economic development in China over the past few decades $[16,17]$.

However, Hukou has continued to prevent internal migrants from enjoying the full benefits of economic and social development in China. On one hand, the fundamental link between Hukou and welfare entitlements remains. The great disparity in economic development across regions in China has been accompanied by increasing inequalities in health and welfare entitlements [18]. It is a common practice in the more developed regions to set up a separate social welfare system for internal migrants, which cannot match those for local Hukou holders [1,2,4]. On the other hand, it is very hard for internal migrants to change Hukou registration $[3,4]$ unless they have obtained higher education and skills. In fact, the majority of internal migrants have moved from rural to urban, had low levels of education, taken up labor-intensive jobs with poor working environments, and lived in poor housing conditions [19]. The high health risks experienced by these internal migrants can be further exacerbated by their poor health literacy and a lack of access to the local welfare system. Several previous studies showed that internal migrants are at a high risk of occupational diseases, infectious and communicable diseases, sexual health problems, maternal health problems, and psychological problems $[11,15]$. In addition, they are more likely to abandon needed health services than their local counterparts, resulting in higher health loss and worse health status [11,15,20-23].

Similar to other social welfare systems, China has developed a Hukou-based social health insurance system, which comprises three schemes: Basic Medical Insurance for Urban Employees (BMIUE), Basic Medical Insurance for Urban Residents (BMIUR), and Rural New Cooperative Medical Scheme (RNCMS) [24-26]. While the BMIUE is co-funded by employer and employee contributions, the other two are heavily subsidized by local governments (including financial transfer from the central government). Under each scheme, there exist many funds administrated by municipal or county levels of government. There are great variations in these insurance policies. Even within a prefecture/county, urban-rural disparities are significant. The existence of thousands of social health insurance funds and a lack of coordination and coherent policies in China has created a great barrier for fund transfer and cross-fund settlements [27]. To maintain financial viability, these funds impose various restrictions on member benefits, such as restricted access to local providers (with a contract) and requirements for deductibles, co-payments and co-insurance. For example, each and every fund signs contracts with its own local providers for medical services delivery. Referral is required to obtain access to services provided by non-contracted providers [28]. Even with a referral, financial compensations for healthcare services outside of the designated region of the fund are always lower than those which are local $[1,28,29]$. Meanwhile, there are tedious paperwork requirements to obtain financial reimbursements $[1,30]$. This makes transfer of insurance enrollment across different funds and regions extremely challenging, if not impossible. Meanwhile, medical services outside of local contracted providers usually attract higher levels of out-of-pocket payments [1], jeopardizing the accessibility of healthcare services of internal migrants $[11,13]$.

Although the vast majority of people in China have been covered by social health insurance, inequality in insurance coverage and entitlements has remained a serious policy concern. Studies 
showed that about $10 \%$ internal migrants failed to enroll in a social health insurance program due to the complexity of the system, which has exposed them to a high financial risk [31]. The internal migrants without social health insurance usually have lower levels of use of both medical services and preventive care compared with their counterparts with social health insurance $[8,17,32-37]$. Some internal migrants were covered by the BMIUE, which enabled them to enjoy a higher level of entitlements and use more healthcare services than those covered by the BMIUR and RNCMS [36-38]. The use of healthcare services by internal migrants is further complicated by the location of insurance funds. Empirical evidence shows that the internal migrants who have enrolled with a social health insurance program outside of their residential location are likely to abandon visits to physicians when needed because of difficulties in accessing the insurance funds $[39,40]$.

Recently, the Chinese government developed a series of policies to address the inequality concerns. These include initiatives to enable internal migrants to obtain better access to local health services $[7,11]$. The BMIUR and RNCMS, for example, have merged in many local governmental catchments although the BMIUE remains separated [14,41]. Meanwhile, insurance funds are encouraged to improve efficiency in fund management and to allow transfer of insurance funds for internal migrants [42]. Internal migrants can choose to enroll in a local social health insurance program outside of their Hukou location [43-46]. Despite high expectations on these new arrangements [14,39,47], early evaluations demonstrated slow progress. Many internal migrants found it difficult to take advantage of the new arrangements [48,49]. It was estimated that in 2017 more than $66 \%$ of internal migrants stayed with their social health insurance schemes in their Hukou location $[12,31,50,51]$. Policy unawareness, fragmentation of insurance policies, high financial costs of fund change, perceived low needs, job insecurity, and high population mobility may have all contributed to the low enrolments in local health insurance [3,52]. As a result, on-the-spot settlements of medical bills emerged as a compromised solution to the mismatch between fund location and provision of healthcare services [52-54]. The on-the-spot settlements of medical bills started in 2014 first within the geographic catchment of a municipality, followed by a provincial-wide arrangement in 2015. In 2016, it became a nationwide arrangement [47,55]. The preliminary evidence showed that the on-the-spot settlements system has indeed stimulated use of medical services by internal immigrants [47,55]. However, its effect remains unclear [2,14,39,47]. In addition, there is paucity in the literature documenting how the insurance arrangements influence health seeking behaviors of the majority of internal migrants, despite some studies into the elderly populations of internal migrants [39,40,47]. Most existing studies reported a higher level of use of medical services in the elderly migrants who enrolled with a local health insurance program than those who did not $[39,40,47]$.

This study aimed to estimate the effect of the on-the-spot medical bill settlement system on the access to both medical services and preventive care by the internal migrants through comparing those with and without local health insurance coverage. The study advances our understanding of the healthcare seeking behaviors of internal migrants by unpacking the components of health services into illness treatments and preventive care. Theoretically, inequalities in preventive care are likely to cause more serious damages to population health than those in illness treatments [56]. However, the impacts of health insurance arrangements on the two components of healthcare services are likely to vary as governmental grants for public health can be drawn to cover preventive care. The study also expands our views on inequalities to those within the internal migrant populations, which can offer some insight into the potential strategies for reducing inequalities. We hypothesized that the effects of the on-the-spot medical bill settlements vary between the rural-to-urban and the urban-to-urban migrants. Unlike previous studies that restricted participants to those aged 60 years and older prior to the nation-wide settlement arrangements [39,40,47,57], our study extended the sample to all of the adult participants and was conducted one year after the national on-the-spot medical bill settlement system was implemented. It was estimated that more than $96 \%$ of internal migrants are younger than 60 years. They usually have quite different healthcare needs and service-seeking behaviors compared to their older counterparts [58]. To the best of our knowledge, this study is the first of its 
kind in China, estimating the effect size of insurance fund location on use of health services in a large nationally representative sample after the implementation of the nationwide on-the-spot medical bill settlement system.

\section{Materials and Methods}

\subsection{Study Design and Data Source}

Data were obtained from the 2017 China Migrants Dynamic Survey (CMDS). The CMDS is a large nationwide cross-sectional questionnaire survey on internal migrants conducted by the National Health Commission of China every year since 2009 [1,2]. The survey contains questions about the demographic and socioeconomic characteristics of the respondents and their family members, as well as their health status and use of health services. Eligible participants of this study included those who were 15 years or older, resided in a residential address outside of their Hukou location (urban district or rural county) for more than one month, and completed the questionnaire on behalf of their households [12,59].

\subsubsection{Setting and Sampling}

The 2017 CMDS survey sample was drawn based on the 2016 China Migrant Population Information System. A multistage stratified probability proportional-to-size (PPS) cluster sampling strategy was adopted to select participants [8,59]. At the first stage, 3150 urban sub-districts and rural townships were selected using the PPS method from 1290 counties/districts of 351 prefectures in 32 provinces. This was followed by a PPS selection of 8500 residential communities/villages from the participating sub-districts/townships. At the third stage, 20 migrant households were randomly sampled from each participating community/village. One respondent $(\geq 15$ years of age) from each household was invited to complete the questionnaire. A total of 169,989 completed questionnaires were returned with a response rate of $99 \%$ [1,59]. In this study, we excluded those $(13,918,8.2 \%)$ without social health insurance and those $(11,115,6.5 \%)$ with more than one social health insurance programs. This resulted in a final sample of 144,956 for data analyses, representing $84.4 \%$ of those being surveyed.

\subsubsection{Data Collection}

The questionnaire was administered through face-to-face interviews using the Computer Assisted Personal Interviewing (CAPI) technique. All of the interviewers were rigorously selected and trained to ensure that they followed the standard protocol [59]. The eligibility of the interviewers was assessed through an examination that demonstrated their proper understanding of the questionnaire and ability to meet the data collection standards developed by the National Health Commission of China. The interviews were conducted in the households of the respondents. Oral informed consent was obtained from each participant prior to the interview. The identified participants who were not accessible were allowed to be replaced by those with similar characteristics in terms of age, gender, location and residential status, preferably from the database recorded in the 2016 China Migrant Population Information System.

A rigorous data verification process was established through the coordination of the National Health Commission of China. The CAPI system identified logical errors that fed back to the interviewers. The completed questionnaires were then checked by a quality assurance officer at each sub-district/township or district/county. The survey supervisors at the provincial or national level performed additional audits on the returned questionnaires through random telephone interviews or site visits. Further details about the survey can be found in the "Handbook of China Migrants Dynamic Survey 2017" [59]. 


\subsection{Data Analysis}

The Andersen's behavioral model, a conceptual framework illustrating the determinants of health services usage, was adopted in this study to guide the construction of statistical models and the selection of indicators/variables [60,61]. This study examined the health behaviors of internal migrants (dependent variables) in terms of medical services for illness treatment and preventive care for maintaining health in line with the defined policy targets of the Chinese government in health development and those used in previous studies [62-65]. According to the Andersen model [60,61], health behaviors are determined by predisposing (e.g., age and sex), enabling (e.g., income and insurance) and needs (e.g., health and illness conditions) factors. The CMDS data were mapped into the three categories of determinants and served as independent variables.

\subsubsection{Dependent Variables}

In this study, two indictors were calculated to measure use of health services in line with those used in previous studies [8,17,32-37].

(1) Registration for essential public health services-this is a proxy indicator measuring access to a package of essential public health services. Respondents were asked whether they had a health record established in the local community health center $(1=$ yes, $0=$ no) [59]. A health record recorded the social and health status of the community resident. It enabled a community health center to deliver essential public health services (e.g., screening and management of chronic conditions) to those who had been recorded. The local governments allocated per capita funding to support a range of population based health care services, targeting the priority areas identified through the personal health records [17].

(2) Visits to physicians when needed as a migrant—-this indicator reflects "realized access" to medical care [65]. The data analysis was restricted to the respondents who reported illness whilst living in the immigrated location $(n=57,664)$. They were asked "What did you do when you felt ill or injured in the last time?". A response of "visiting a physician" (regardless of which facilities) was coded as " 1 ". For those who sought self-medication or did not seek medical attention, a code of " 0 " was assigned [59].

\subsubsection{Independent and Control Variables}

The effects of health insurance arrangements on the use of health services were the major focus of this study. The location of insurance funds was selected to measure health insurance arrangements and served as the independent variable. Respondents were asked whether they enrolled in a social health fund at their residential location $(1=$ yes; $0=$ no).

The control variables were selected according to the Andersen model [60,61], which were used for the purpose of adjustment of confounding effects. In this study, gender, age and marital status fell into the category of predisposing factors, while educational attainment, employment, household income, and type of social health insurance were considered as enabling factors. Health needs were measured using three indicators: self-rating health, two-week morbidity and chronic conditions. Respondents were asked to report their gender (male vs female), age (15-24, 25-34, 35-44, 45-54, $55+$ years), marital status (never married/single, married, divorced, widowed), educational attainment (illiterate, primary school, junior middle school, senior middle school, university/college), employment (employed, unemployed), household income, and type of insurance funds (BMIUE, BMIUR/RNCMS, and others). They were also asked to rate their overall health (good, general, poor), and to report experiences of acute illness over a two-week period (no or yes) and chronic conditions (hypertension and diabetes) diagnosed by a doctor (no or yes). The data about household income were transformed into a ranking within respective province (<percentile 20, percentile 20-39, percentile 40-59, percentile $60-79$, and $\geq$ percentile 80 ) for data analyses. 
Significant regional variations in social and health development exist in China. Such contextual characteristics could play a significant role in shaping the use of health services. Therefore, contextual characteristics were included as another layer of control variables (enabling factor) in this study. Immigrated destination (counties/districts) served as an indicator reflecting the contextual differences of the study participants. Each county/district would have its special socioeconomic environment and insurance policies, including rules about fund transfer and portability of insurance entitlements. However, further inclusion of these more specific variables in data analyses would simply overlap with the county/district variable.

\subsubsection{Statistical Analysis}

Multilevel modelling has been widely used in analyzing data with a cluster structure $[56,66]$. In this study, two-level logistic regression models were established to compare the use of health services between the internal migrants with and without local health insurance, after adjustment for variations in the control variables at the individual level (fixed effects) and the county/district level (random effect).

We constructed an empty model first with only a random intercept to determine whether the contextual dimension was appropriate to be treated as the second level. The intraclass correlation coefficients (ICCs) of the empty models showed statistical significance, indicating that a two-level modeling was appropriate for this study [56,67]: 0.45 for having a health record and 0.10 for the use of medical services at the county/district level. The two-level logistic regression models were then established as the following:

$$
\log i t\left(Y_{i j}\right)=\left(\beta_{0}+\beta_{\text {place }} X_{\text {place } \_i j}\right)+\sum_{h=1}^{n} \beta_{\text {control_h } h} X_{\text {control_hij }}+\left(u_{0 j}+u_{\text {place_j } j} X_{\text {place_ij } i j}\right)+\varepsilon_{0 i j}
$$

This model estimates the main effect of insurance fund location, where $Y_{i j}$ represents the use of health services at an individual level ( $i$ refers to each respondent, $j$ refers to each county/district). $X_{\text {place }} i j$ indicates the location of health insurance fund enrolled by respondent $i$ in county/district $j . X_{\text {control_hij }}$ represents the control variables entered into the models, including gender, age, educational attainment, marital status, employment, ranking of household income, type of health insurance, self-reported health, two-week morbidity, and chronic conditions. $\beta_{\text {place }}$ and $\beta_{\text {control_h }}$ represent the fixed effects of the location of health insurance funds and control variables on the use of health services at the individual level (level 1), respectively. $u_{\text {place_j }}$ indicates the random effect of $X_{\text {place } i j}$ on the use of health services at the contextual level (level 2). $\beta_{0}$ is the fixed intercept. $u_{0 \_}$indicates the random intercept. $\varepsilon_{0 i j}$ is the random error at level 1.

We then added the interaction effects between location and type of health insurance funds into the models in order to better understand the effects of cross-county/district insurance arrangements. We also performed sub-group analyses, comparing the effects of insurance arrangements on the rural-to-urban and urban-to-urban migrants.

All analyses were performed using STATA version 16.0 (SE) for Windows (StataCorp LLC, College Station, TX, USA). The pweight method based on the sampling design was used to weigh the cases and the robust method was use to estimate variance-covariance matrix (VCE) corresponding to the parameter estimates [68]. The effects of health insurance fund location on the use of health services were presented using adjusted odds ratio (AOR) and average marginal effects (AME) [39]. A higher AOR or AME indicates a higher effect. The statistical significance level was set at 0.05 . 


\section{Results}

\subsection{Characteristics of Respondents}

Slightly more than half of the respondents (51.65\%) were male. About $6 \%$ of the respondents were older than 55 years; $17 \%$ had a university degree. The majority $(83.26 \%)$ were married at the time of the survey. Although most (82.18\%) of the respondents had a job, only $18.35 \%$ were enrolled with the BMIUE. Rural-to-urban migrants accounted for about $80 \%$ of the respondents (Table 1 ).

Less than one-third (30.28\%) of the respondents had a health record. More than half (50.77\%) visited a physician when they felt ill or were injured. About $24 \%$ of the respondents enrolled in a social health insurance scheme locally, wherever they resided. Those who were female $(p<0.05)$, young, healthy, received higher education, single, employed, had higher income, enrolled with the BMIUE, and immigrated from urban to urban $(p<0.001)$ were more likely to enroll in a health insurance scheme locally (Table 1).

\subsection{Having a Health Record}

The respondents with local health insurance coverage were more likely to have a health record than those without local health insurance coverage (35.31\% vs. 28.61\%, $p<0.001)$. The odds of having a health record in the respondents with local health insurance coverage were 1.47 times $(\mathrm{AOR}=1.47$, $95 \% \mathrm{CI}=1.30-1.65)$ of those without local health insurance coverage: 6.1 percentage points higher $(\mathrm{AME}=6.1 \%, 95 \% \mathrm{CI}: 4.3-7.8 \%)$ after controlling for variations in other variables. The effect sizes were similar between the rural-to-urban (AME $=6.8 \%, 95 \% \mathrm{CI}: 4.9-8.6 \%$ ) and the urban-to-urban $(\mathrm{AME}=6.8 \%, 95 \% \mathrm{CI}: 3.2-10.4 \%$ ) migrants (Table 2$)$.

The contextual variable "county/district" contributed to $44 \%$ of the total variance of the dependent variable (having heath records): $45 \%$ for the rural-to-urban migrants and $37 \%$ for the urban-to-urban migrants. The regression models also showed that female migrants were more likely to have a health record than male migrants $(\mathrm{AOR}=1.21, p<0.001)$. Those who were married $(\mathrm{AOR}=1.32, p<0.001)$, had higher levels of education ( $\mathrm{AOR}=1.41-2.08, p<0.001)$, and had higher household income $(\mathrm{AOR}=1.02-1.11, p<0.05)$ were more likely to have a health record than others. The respondents who reported worse health were less likely to have a health record than those reporting better health $(\mathrm{AOR}=0.73-0.80, p<0.05)$. Chronic morbidity was associated with higher odds of having health records $(\mathrm{AOR}=1.30, p<0.001)$. These effects were consistent between the rural-to-urban and the urban-to-urban migrants (Table 2).

Although the type of health insurance had no significant association with the establishment of health records $(p>0.05)$, the interaction effect between location and type of health insurance on the establishment of health records was statistically significant (Supplementary File Tables S1 and S2). The location effect was lower on the establishment of health records in those covered by the BMIUE (AOR $=0.71, p=0.01$, Table S1) in comparison with those covered by the merged insurance BMIUR/RNCMS.

\subsection{Use of Medical Services}

The respondents with local health insurance coverage were more likely to visit physicians when needed $(\mathrm{AOR}=1.18,95 \% \mathrm{CI}=1.06-1.30): 3.5$ percentage points higher than those without local health insurance coverage after controlling for variations in other variables ( $\mathrm{AME}=3.5 \%, 95 \% \mathrm{CI}$ : $1.3-5.8 \%$ ). However, such an association was only statistically significant in the rural-to-urban migrants $(\mathrm{AME}=4.8 \%, 95 \% \mathrm{CI}: 1.8-7.7 \%)$ (Table 3). 
Table 1. Characteristics of respondents with and without local social health insurance.

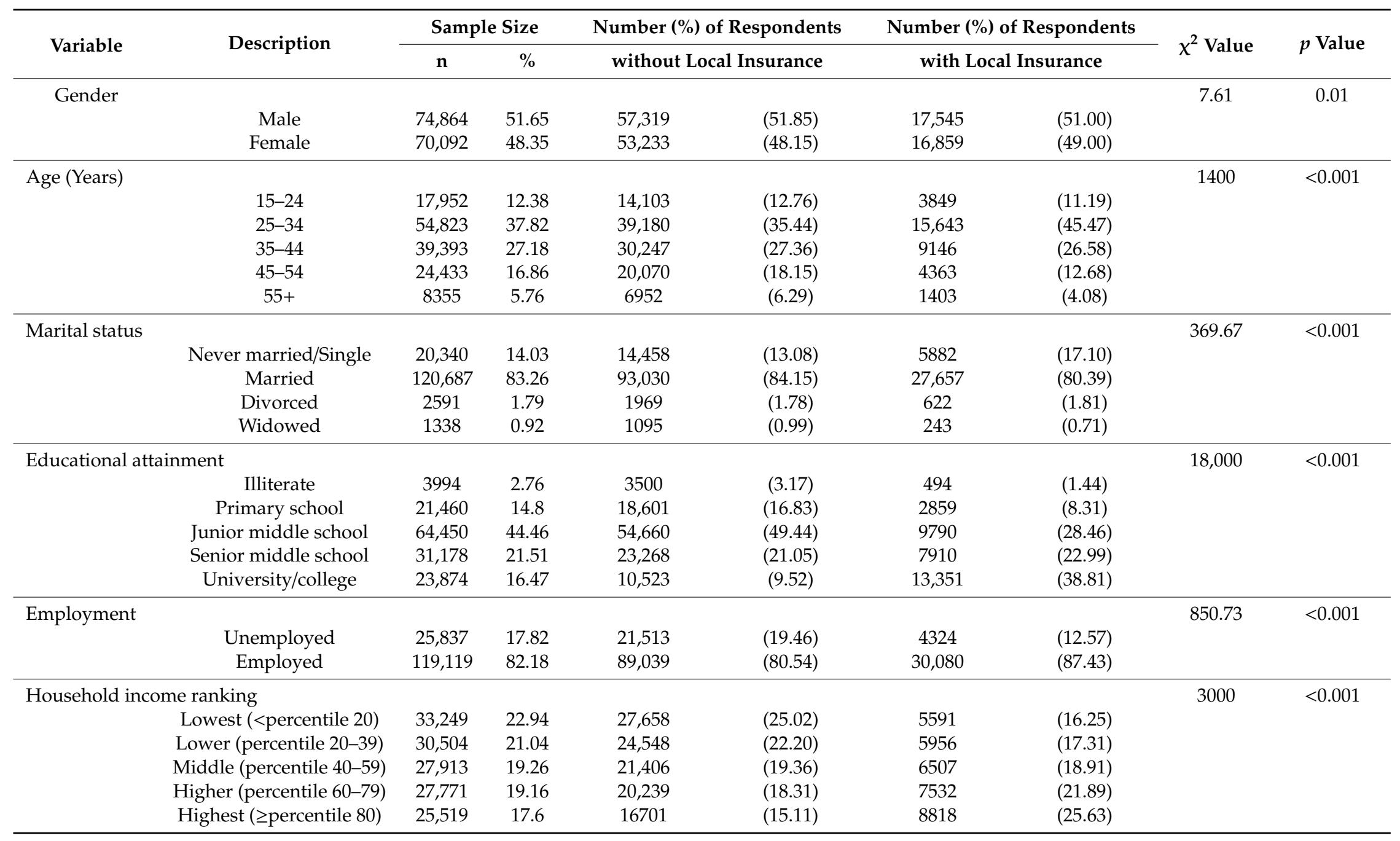


Table 1. Cont

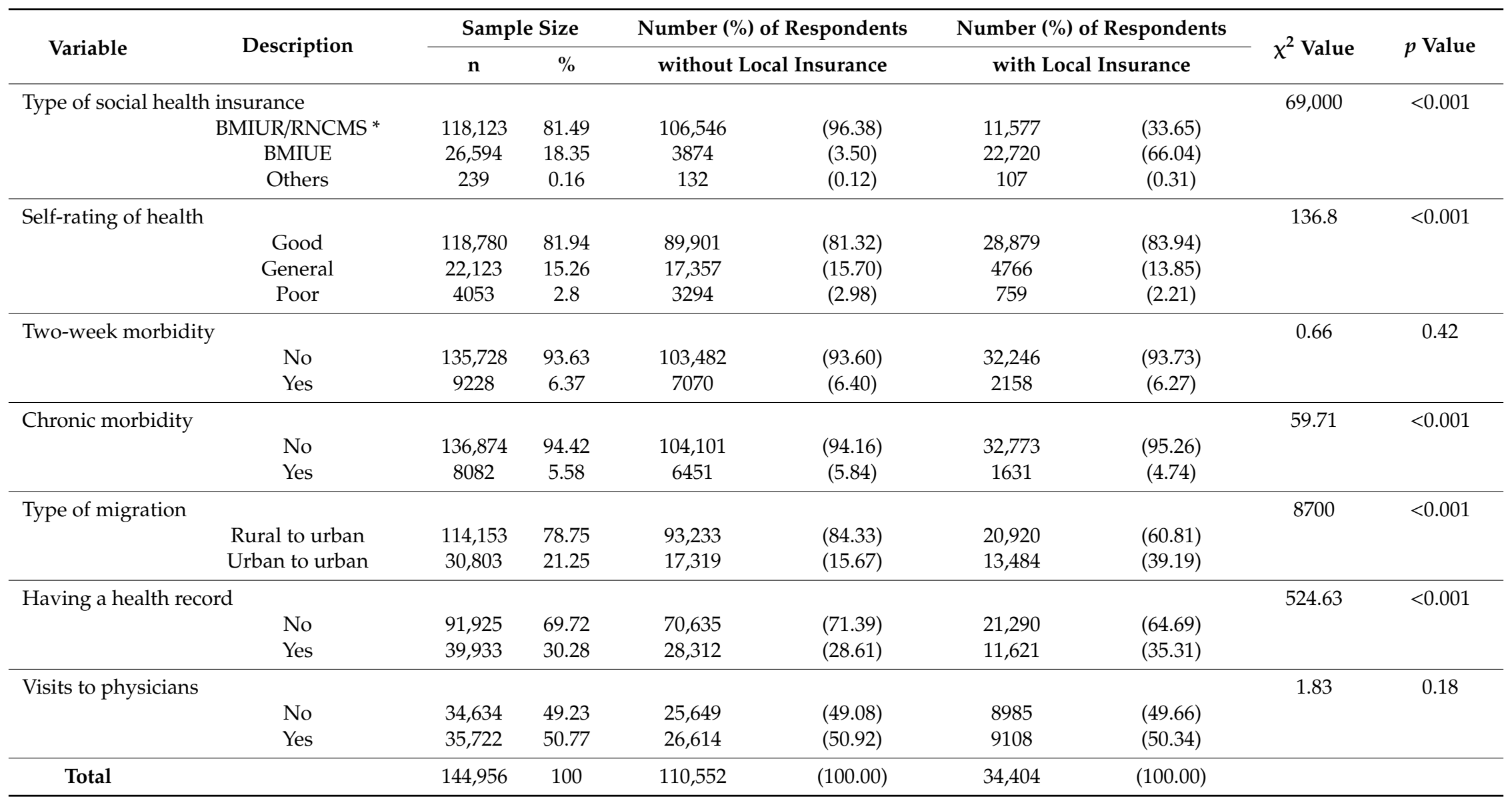

Note: * BMIUR-Basic Medical Insurance for Urban Residents; RNCMS-Rural New Cooperative Medical Scheme; BMIUE-Basic Medical Insurance for Urban Employees. 
Table 2. Factors associated with the establishment of personal health records: results of two-level logistic regression models.

\begin{tabular}{|c|c|c|c|c|c|c|c|c|c|c|c|c|c|c|c|c|}
\hline \multirow{2}{*}{\multicolumn{2}{|c|}{ Variables }} & \multicolumn{5}{|c|}{ Rural to Urban Respondents } & \multicolumn{5}{|c|}{ Urban to Urban Respondents } & \multicolumn{5}{|c|}{ All Respondents } \\
\hline & & \multirow{3}{*}{$\begin{array}{c}{\mathrm{AOR} / \mathrm{ICC}^{+}}^{+} \\
1.56\end{array}$} & \multirow{3}{*}{$\begin{array}{c}\text { SE } \\
\\
0.10\end{array}$} & \multirow{3}{*}{$\begin{array}{l}p \text { Value } \\
<0.001\end{array}$} & \multicolumn{2}{|c|}{$95 \% \mathrm{CI}$} & \multirow{3}{*}{$\begin{array}{c}\mathrm{AOR} / \mathrm{ICC} \\
1.46\end{array}$} & \multirow{3}{*}{$\begin{array}{l}\text { SE } \\
\\
0.17\end{array}$} & \multirow{3}{*}{$\begin{array}{r}p \text { Value } \\
<0.001\end{array}$} & \multicolumn{2}{|c|}{$95 \% \mathrm{CI}$} & \multirow{3}{*}{$\begin{array}{c}\text { AOR/ICC } \\
1.47 \\
\end{array}$} & \multirow{3}{*}{$\begin{array}{l}\text { SE } \\
\\
0.09\end{array}$} & \multirow{3}{*}{$\begin{array}{l}p \text { Value } \\
<0.001\end{array}$} & \multicolumn{2}{|c|}{$95 \% \mathrm{CI}$} \\
\hline \multicolumn{8}{|c|}{$\begin{array}{l}\text { Fixed effects (Level 1) } \\
\end{array}$} & & & & & & & & & \\
\hline $\begin{array}{l}\text { Enrolment with a local social } \\
\text { health insurance program }\end{array}$ & $\begin{array}{c}\text { No (reference) } \\
\text { Yes* }\end{array}$ & & & & 1.38 & 1.77 & & & & 1.16 & 1.83 & & & & 1.30 & 1.65 \\
\hline Gender & $\begin{array}{l}\text { Male (reference) } \\
\text { Female }\end{array}$ & 1.21 & 0.04 & $<0.001$ & 1.13 & 1.29 & 1.19 & 0.07 & $<0.001$ & 1.06 & 1.33 & 1.21 & 0.03 & $<0.001$ & 1.14 & 1.28 \\
\hline Age (Years) & $\begin{array}{c}15-24 \text { (reference) } \\
25-34 \\
35-44 \\
45-54 \\
55+\end{array}$ & $\begin{array}{l}1.00 \\
1.04 \\
0.93 \\
1.09\end{array}$ & $\begin{array}{l}0.07 \\
0.08 \\
0.07 \\
0.15\end{array}$ & $\begin{array}{l}0.95 \\
0.62 \\
0.39 \\
0.51\end{array}$ & $\begin{array}{l}0.87 \\
0.90 \\
0.80 \\
0.84\end{array}$ & $\begin{array}{l}1.15 \\
1.20 \\
1.09 \\
1.43\end{array}$ & $\begin{array}{l}1.10 \\
1.01 \\
1.02 \\
1.31\end{array}$ & $\begin{array}{l}0.12 \\
0.12 \\
0.15 \\
0.19\end{array}$ & $\begin{array}{l}0.38 \\
0.92 \\
0.89 \\
0.07\end{array}$ & $\begin{array}{l}0.89 \\
0.80 \\
0.76 \\
0.98\end{array}$ & $\begin{array}{l}1.36 \\
1.27 \\
1.36 \\
1.75\end{array}$ & $\begin{array}{l}1.01 \\
1.02 \\
0.95 \\
1.20\end{array}$ & $\begin{array}{l}0.07 \\
0.08 \\
0.07 \\
0.14\end{array}$ & $\begin{array}{l}0.85 \\
0.79 \\
0.45 \\
0.13\end{array}$ & $\begin{array}{l}0.88 \\
0.88 \\
0.82 \\
0.95\end{array}$ & $\begin{array}{l}1.16 \\
1.18 \\
1.09 \\
1.51\end{array}$ \\
\hline Marital status & $\begin{array}{c}\text { Never married/Single (reference) } \\
\text { Married } \\
\text { Divorced } \\
\text { Widowed } \\
\end{array}$ & $\begin{array}{l}1.31 \\
1.19 \\
1.12\end{array}$ & $\begin{array}{l}0.09 \\
0.15 \\
0.22\end{array}$ & $\begin{array}{c}<0.001 \\
0.18 \\
0.55 \\
\end{array}$ & $\begin{array}{l}1.14 \\
0.92 \\
0.77\end{array}$ & $\begin{array}{l}1.50 \\
1.54 \\
1.64\end{array}$ & $\begin{array}{l}1.31 \\
1.38 \\
1.22\end{array}$ & $\begin{array}{l}0.14 \\
0.24 \\
0.42\end{array}$ & $\begin{array}{l}0.01 \\
0.07 \\
0.57\end{array}$ & $\begin{array}{l}1.06 \\
0.98 \\
0.61\end{array}$ & $\begin{array}{l}1.62 \\
1.94 \\
2.41\end{array}$ & $\begin{array}{l}1.32 \\
1.26 \\
1.12\end{array}$ & $\begin{array}{l}0.10 \\
0.15 \\
0.20\end{array}$ & $\begin{array}{c}<0.001 \\
0.05 \\
0.52 \\
\end{array}$ & $\begin{array}{l}1.14 \\
1.00 \\
0.80\end{array}$ & $\begin{array}{l}1.53 \\
1.58 \\
1.58 \\
\end{array}$ \\
\hline Educational attainment & $\begin{array}{l}\text { Illiterate (reference) } \\
\text { Primary school } \\
\text { Junior middle school } \\
\text { Senior middle school } \\
\text { University/college }\end{array}$ & $\begin{array}{l}1.34 \\
1.55 \\
1.84 \\
1.97\end{array}$ & $\begin{array}{l}0.14 \\
0.16 \\
0.22 \\
0.24\end{array}$ & $\begin{array}{l}0.01 \\
<0.001 \\
<0.001 \\
<0.001\end{array}$ & $\begin{array}{l}1.09 \\
1.27 \\
1.45 \\
1.54\end{array}$ & $\begin{array}{l}1.64 \\
1.90 \\
2.33 \\
2.50\end{array}$ & $\begin{array}{l}1.58 \\
2.02 \\
2.15 \\
2.28\end{array}$ & $\begin{array}{l}0.58 \\
0.73 \\
0.79 \\
0.88\end{array}$ & $\begin{array}{l}0.22 \\
0.05 \\
0.04 \\
0.03\end{array}$ & $\begin{array}{l}0.77 \\
1.00 \\
1.05 \\
1.07\end{array}$ & $\begin{array}{l}3.25 \\
4.09 \\
4.42 \\
4.85\end{array}$ & $\begin{array}{l}1.41 \\
1.66 \\
1.94 \\
2.08\end{array}$ & $\begin{array}{l}0.14 \\
0.16 \\
0.22 \\
0.23\end{array}$ & $\begin{array}{l}<0.001 \\
<0.001 \\
<0.001 \\
<0.001\end{array}$ & $\begin{array}{l}1.16 \\
1.37 \\
1.56 \\
1.67\end{array}$ & $\begin{array}{l}1.71 \\
2.01 \\
2.42 \\
2.57\end{array}$ \\
\hline Employment & $\begin{array}{l}\text { Unemployed (reference) } \\
\text { Employed }\end{array}$ & 0.94 & 0.04 & 0.11 & 0.86 & 1.01 & 0.98 & 0.08 & 0.78 & 0.83 & 1.15 & 0.93 & 0.03 & 0.06 & 0.87 & 1.00 \\
\hline Household income ranking & $\begin{array}{l}\text { Lowest (<percentile 20, reference) } \\
\text { Lower (percentile 20-39.9) } \\
\text { Middle (percentile 40-59.9) } \\
\text { Higher (percentile 60-79.9) } \\
\text { Highest ( } \geq \text { percentile 80) }\end{array}$ & $\begin{array}{l}1.13 \\
1.12 \\
1.01 \\
1.11\end{array}$ & $\begin{array}{l}0.05 \\
0.05 \\
0.05 \\
0.07\end{array}$ & $\begin{array}{l}0.01 \\
0.01 \\
0.76 \\
0.10\end{array}$ & $\begin{array}{l}1.03 \\
1.03 \\
0.93 \\
0.98\end{array}$ & $\begin{array}{l}1.24 \\
1.23 \\
1.11 \\
1.25\end{array}$ & $\begin{array}{l}1.02 \\
1.03 \\
1.02 \\
0.93\end{array}$ & $\begin{array}{l}0.07 \\
0.10 \\
0.10 \\
0.10\end{array}$ & $\begin{array}{l}0.80 \\
0.79 \\
0.88 \\
0.52\end{array}$ & $\begin{array}{l}0.89 \\
0.85 \\
0.84 \\
0.75\end{array}$ & $\begin{array}{l}1.17 \\
1.25 \\
1.23 \\
1.16\end{array}$ & $\begin{array}{l}1.11 \\
1.10 \\
1.02 \\
1.06\end{array}$ & $\begin{array}{l}0.05 \\
0.05 \\
0.04 \\
0.06\end{array}$ & $\begin{array}{l}0.01 \\
0.02 \\
0.61 \\
0.31\end{array}$ & $\begin{array}{l}1.02 \\
1.01 \\
0.94 \\
0.95\end{array}$ & $\begin{array}{l}1.20 \\
1.20 \\
1.11 \\
1.17\end{array}$ \\
\hline Type of social health insurance & $\begin{array}{c}\text { BMIUR/RNCMS (reference) } \\
\text { BMIUE } \\
\text { Others }\end{array}$ & $\begin{array}{l}1.05 \\
2.09\end{array}$ & $\begin{array}{l}0.10 \\
1.58\end{array}$ & $\begin{array}{l}0.59 \\
0.33\end{array}$ & $\begin{array}{l}0.88 \\
0.48\end{array}$ & $\begin{array}{l}1.26 \\
9.16\end{array}$ & $\begin{array}{l}1.03 \\
1.27\end{array}$ & $\begin{array}{l}0.14 \\
0.45\end{array}$ & $\begin{array}{l}0.82 \\
0.50\end{array}$ & $\begin{array}{l}0.79 \\
0.63\end{array}$ & $\begin{array}{l}1.34 \\
2.54\end{array}$ & $\begin{array}{l}1.09 \\
1.43\end{array}$ & $\begin{array}{l}0.10 \\
0.48\end{array}$ & $\begin{array}{l}0.34 \\
0.29\end{array}$ & $\begin{array}{l}0.91 \\
0.74\end{array}$ & $\begin{array}{l}1.30 \\
2.76\end{array}$ \\
\hline Self-rating of health & $\begin{array}{l}\text { Good (reference) } \\
\text { General } \\
\text { Poor }\end{array}$ & $\begin{array}{l}0.75 \\
0.83\end{array}$ & $\begin{array}{l}0.04 \\
0.08\end{array}$ & $\begin{array}{c}<0.001 \\
0.05\end{array}$ & $\begin{array}{l}0.67 \\
0.69\end{array}$ & $\begin{array}{l}0.84 \\
1.00\end{array}$ & $\begin{array}{l}0.66 \\
0.74\end{array}$ & $\begin{array}{l}0.04 \\
0.12\end{array}$ & $<0.001$ & $\begin{array}{l}0.58 \\
0.53\end{array}$ & $\begin{array}{l}0.75 \\
1.03\end{array}$ & $\begin{array}{l}0.73 \\
0.80\end{array}$ & $\begin{array}{l}0.03 \\
0.06\end{array}$ & $\begin{array}{c}<0.001 \\
0.01\end{array}$ & $\begin{array}{l}0.67 \\
0.69\end{array}$ & $\begin{array}{l}0.80 \\
0.93\end{array}$ \\
\hline Two-week morbidity & $\begin{array}{l}\text { No (reference) } \\
\text { Yes }\end{array}$ & 1.01 & 0.09 & 0.92 & 0.85 & 1.20 & 1.11 & 0.14 & 0.40 & 0.87 & 1.41 & 1.04 & 0.08 & 0.63 & 0.89 & 1.21 \\
\hline Chronic morbidity & $\begin{array}{l}\text { No (reference) } \\
\text { Yes }\end{array}$ & 1.24 & 0.07 & $<0.001$ & 1.11 & 1.38 & 1.44 & 0.17 & $<0.001$ & 1.13 & 1.82 & 1.30 & 0.06 & $<0.001$ & 1.18 & 1.43 \\
\hline \multicolumn{17}{|c|}{ Radom effects (Level 2) } \\
\hline & $\begin{array}{l}\text { Variance (enrolment with local social } \\
\text { health insurance) }\end{array}$ & 0.57 & 0.08 & & 0.44 & 0.75 & 0.70 & 0.15 & & 0.46 & 1.07 & 0.58 & 0.11 & & 0.39 & 0.85 \\
\hline & Variance (intercept) & 2.74 & 0.18 & & 2.42 & 3.11 & 1.92 & 0.17 & & 1.62 & 2.27 & 2.56 & 0.18 & & 2.22 & 2.95 \\
\hline & ICC & & & & & & & & & & & & & & & \\
\hline & $\begin{array}{l}\text { Empty model } \\
\text { Full model }\end{array}$ & $\begin{array}{l}0.45 \\
0.45\end{array}$ & $\begin{array}{l}0.02 \\
0.02\end{array}$ & & $\begin{array}{l}0.42 \\
0.42\end{array}$ & $\begin{array}{l}0.48 \\
0.49\end{array}$ & $\begin{array}{l}0.36 \\
0.37\end{array}$ & $\begin{array}{l}0.02 \\
0.02\end{array}$ & & $\begin{array}{l}0.32 \\
0.33\end{array}$ & $\begin{array}{l}0.40 \\
0.41\end{array}$ & $\begin{array}{l}0.45 \\
0.44\end{array}$ & $\begin{array}{l}0.01 \\
0.02\end{array}$ & & $\begin{array}{l}0.42 \\
0.40\end{array}$ & $\begin{array}{l}0.48 \\
0.47\end{array}$ \\
\hline
\end{tabular}


Table 2. Cont

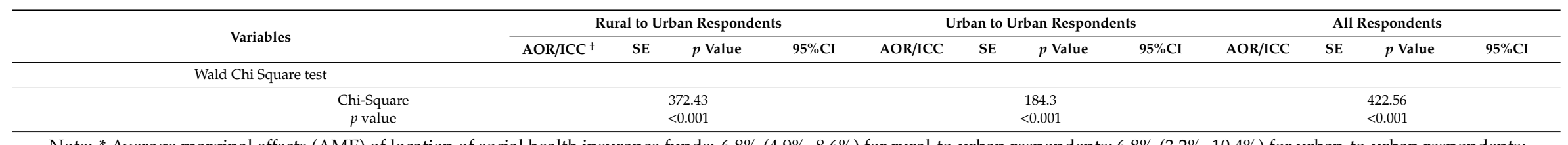

Note: * Average marginal effects (AME) of location of social health insurance funds: $6.8 \%(4.9 \%, 8.6 \%)$ for rural-to-urban respondents; $6.8 \%$ (3.2\%, $10.4 \%)$ for urban-to-urban respondents;

$6.1 \%(4.3 \%, 7.8 \%)$ for all respondents. ${ }^{\dagger}$ ICC: intraclass correlation coefficient; AOR: adjusted odds ratio; SE: standard error; CI: confidence interval.

Table 3. Factors associated with visits to local physicians when needed: results of two-level logistic regression models.

\begin{tabular}{|c|c|c|c|c|c|c|c|c|c|c|c|c|c|c|c|c|}
\hline \multirow{2}{*}{\multicolumn{2}{|c|}{ Variables }} & \multicolumn{5}{|c|}{ Rural to Urban Respondents } & \multicolumn{5}{|c|}{ Urban to Urban Respondents } & \multicolumn{5}{|c|}{ All Respondents } \\
\hline & & \multirow{3}{*}{$\begin{array}{c}\mathrm{AOR}^{\mathrm{ICC}}{ }^{+} \\
1.24 \\
\end{array}$} & \multirow{3}{*}{$\begin{array}{c}\text { SE } \\
\\
0.08 \\
\end{array}$} & \multirow{3}{*}{$\begin{array}{r}p \text { Value } \\
<0.001\end{array}$} & \multicolumn{2}{|c|}{$95 \% \mathrm{CI}$} & \multirow[t]{2}{*}{ AOR/ICC } & \multirow[t]{2}{*}{ SE } & \multirow[t]{2}{*}{$p$ Value } & \multicolumn{2}{|c|}{$95 \% \mathrm{CI}$} & \multirow[t]{2}{*}{ AOR/ICC } & \multirow[t]{2}{*}{ SE } & \multirow[t]{2}{*}{$p$ Value } & \multicolumn{2}{|c|}{$95 \%$ CI } \\
\hline Fixed & ts (Level I) & & & & & & & & & & & & & & & \\
\hline $\begin{array}{l}\text { Enrolment with a local social } \\
\text { health insurance program }\end{array}$ & $\begin{array}{c}\text { No (reference) } \\
\text { Yes* }\end{array}$ & & & & 1.09 & 1.42 & 1.09 & 0.09 & 0.32 & 0.92 & 1.28 & 1.18 & 0.06 & $<0.001$ & 1.06 & 1.3 \\
\hline Gender & $\begin{array}{l}\text { Male (reference) } \\
\text { Female }\end{array}$ & 1.06 & 0.04 & 0.10 & 0.99 & 1.13 & 1.15 & 0.07 & 0.03 & 1.02 & 1.30 & 1.08 & 0.03 & 0.01 & 1.02 & 1.1 \\
\hline Age (Years) & $\begin{array}{c}15-24 \text { (reference) } \\
25-34 \\
35-44 \\
45-54 \\
55+\end{array}$ & $\begin{array}{l}1.09 \\
1.05 \\
0.91 \\
1.02\end{array}$ & $\begin{array}{l}0.08 \\
0.08 \\
0.07 \\
0.11\end{array}$ & $\begin{array}{l}0.21 \\
0.47 \\
0.24 \\
0.88\end{array}$ & $\begin{array}{l}0.95 \\
0.91 \\
0.79 \\
0.82\end{array}$ & $\begin{array}{l}1.25 \\
1.22 \\
1.06 \\
1.27\end{array}$ & $\begin{array}{l}0.90 \\
0.82 \\
0.84 \\
0.85\end{array}$ & $\begin{array}{l}0.13 \\
0.13 \\
0.13 \\
0.17\end{array}$ & $\begin{array}{l}0.46 \\
0.21 \\
0.28 \\
0.42\end{array}$ & $\begin{array}{l}0.68 \\
0.61 \\
0.62 \\
0.58\end{array}$ & $\begin{array}{l}1.19 \\
1.12 \\
1.15 \\
1.26\end{array}$ & $\begin{array}{l}1.05 \\
1.00 \\
0.89 \\
0.97\end{array}$ & $\begin{array}{l}0.06 \\
0.07 \\
0.06 \\
0.09\end{array}$ & $\begin{array}{l}0.42 \\
0.98 \\
0.10 \\
0.75\end{array}$ & $\begin{array}{l}0.93 \\
0.87 \\
0.78 \\
0.82\end{array}$ & $\begin{array}{l}1.1 \\
1.1 \\
1.02 \\
1.1\end{array}$ \\
\hline Marital status & $\begin{array}{c}\text { Never married/Single (reference) } \\
\text { Married } \\
\text { Divorced } \\
\text { Widowed } \\
\end{array}$ & $\begin{array}{l}1.02 \\
1.03 \\
0.90 \\
\end{array}$ & $\begin{array}{l}0.08 \\
0.14 \\
0.19 \\
\end{array}$ & $\begin{array}{l}0.75 \\
0.83 \\
0.60 \\
\end{array}$ & $\begin{array}{l}0.89 \\
0.78 \\
0.60 \\
\end{array}$ & $\begin{array}{l}1.18 \\
1.36 \\
1.34 \\
\end{array}$ & $\begin{array}{l}1.08 \\
1.13 \\
1.47 \\
\end{array}$ & $\begin{array}{l}0.13 \\
0.28 \\
0.41 \\
\end{array}$ & $\begin{array}{l}0.55 \\
0.63 \\
0.17 \\
\end{array}$ & $\begin{array}{l}0.85 \\
0.70 \\
0.85 \\
\end{array}$ & $\begin{array}{l}1.37 \\
1.83 \\
2.53 \\
\end{array}$ & $\begin{array}{l}1.03 \\
1.04 \\
0.99 \\
\end{array}$ & $\begin{array}{l}0.08 \\
0.13 \\
0.18 \\
\end{array}$ & $\begin{array}{l}0.73 \\
0.78 \\
0.98 \\
\end{array}$ & $\begin{array}{l}0.89 \\
0.81 \\
0.70 \\
\end{array}$ & $\begin{array}{l}1.1 \\
1.3 \\
1.4 \\
\end{array}$ \\
\hline Educational attainment & $\begin{array}{c}\text { Illiterate (reference) } \\
\text { Primary school } \\
\text { Junior middle school } \\
\text { Senior middle school } \\
\text { University/college } \\
\end{array}$ & $\begin{array}{l}1.05 \\
1.14 \\
1.09 \\
1.12 \\
\end{array}$ & $\begin{array}{l}0.10 \\
0.11 \\
0.15 \\
0.13 \\
\end{array}$ & $\begin{array}{l}0.61 \\
0.17 \\
0.52 \\
0.37 \\
\end{array}$ & $\begin{array}{l}0.87 \\
0.94 \\
0.84 \\
0.88 \\
\end{array}$ & $\begin{array}{l}1.27 \\
1.38 \\
1.43 \\
1.41 \\
\end{array}$ & $\begin{array}{l}0.64 \\
0.66 \\
0.72 \\
0.74 \\
\end{array}$ & $\begin{array}{l}0.19 \\
0.20 \\
0.21 \\
0.23 \\
\end{array}$ & $\begin{array}{l}0.13 \\
0.16 \\
0.27 \\
0.32 \\
\end{array}$ & $\begin{array}{l}0.36 \\
0.37 \\
0.41 \\
0.40 \\
\end{array}$ & $\begin{array}{l}1.14 \\
1.18 \\
1.29 \\
1.34 \\
\end{array}$ & $\begin{array}{l}1.01 \\
1.09 \\
1.06 \\
1.07 \\
\end{array}$ & $\begin{array}{l}0.10 \\
0.10 \\
0.12 \\
0.10 \\
\end{array}$ & $\begin{array}{l}0.94 \\
0.32 \\
0.61 \\
0.46 \\
\end{array}$ & $\begin{array}{l}0.84 \\
0.92 \\
0.85 \\
0.89 \\
\end{array}$ & $\begin{array}{l}1.2 \\
1.2 \\
1.3 \\
1.2 \\
\end{array}$ \\
\hline Employment & $\begin{array}{c}\text { Unemployed (reference) } \\
\text { Employed }\end{array}$ & 0.89 & 0.04 & 0.02 & 0.81 & 0.98 & 1.13 & 0.12 & 0.24 & 0.92 & 1.40 & 0.94 & 0.04 & 0.13 & 0.86 & 1.02 \\
\hline Household income ranking & $\begin{array}{c}\text { Lowest (<percentile 20, reference) } \\
\text { Lower (percentile 20-39.9) } \\
\text { Middle (percentile 40-59.9) } \\
\text { Higher (percentile 60-79.9) } \\
\text { Highest }(\geq \text { percentile } 80 \text { ) }\end{array}$ & $\begin{array}{l}1.02 \\
1.00 \\
1.02 \\
1.07 \\
\end{array}$ & $\begin{array}{l}0.05 \\
0.06 \\
0.05 \\
0.08 \\
\end{array}$ & $\begin{array}{l}0.74 \\
0.95 \\
0.65 \\
0.42 \\
\end{array}$ & $\begin{array}{l}0.93 \\
0.90 \\
0.93 \\
0.92 \\
\end{array}$ & $\begin{array}{l}1.11 \\
1.12 \\
1.13 \\
1.24 \\
\end{array}$ & $\begin{array}{l}1.14 \\
1.15 \\
1.03 \\
0.96 \\
\end{array}$ & $\begin{array}{l}0.13 \\
0.14 \\
0.11 \\
0.12 \\
\end{array}$ & $\begin{array}{l}0.24 \\
0.24 \\
0.78 \\
0.77 \\
\end{array}$ & $\begin{array}{l}0.92 \\
0.91 \\
0.84 \\
0.76 \\
\end{array}$ & $\begin{array}{l}1.42 \\
1.46 \\
1.26 \\
1.23 \\
\end{array}$ & $\begin{array}{l}1.03 \\
1.03 \\
1.01 \\
1.01 \\
\end{array}$ & $\begin{array}{l}0.05 \\
0.05 \\
0.05 \\
0.07 \\
\end{array}$ & $\begin{array}{l}0.49 \\
0.63 \\
0.82 \\
0.84 \\
\end{array}$ & $\begin{array}{l}0.95 \\
0.93 \\
0.92 \\
0.88\end{array}$ & $\begin{array}{l}1.12 \\
1.1 \\
1.1 \\
1.1 \\
\end{array}$ \\
\hline Type of social health insurance & $\begin{array}{l}\text { BMIUR/RNCMS (reference) } \\
\text { BMIUE } \\
\text { Others }\end{array}$ & $\begin{array}{l}0.83 \\
6.43\end{array}$ & $\begin{array}{l}0.07 \\
4.49\end{array}$ & $\begin{array}{l}0.02 \\
0.01\end{array}$ & $\begin{array}{l}0.71 \\
1.63\end{array}$ & $\begin{array}{c}0.97 \\
25.29\end{array}$ & $\begin{array}{l}0.95 \\
1.06\end{array}$ & $\begin{array}{l}0.09 \\
0.24\end{array}$ & $\begin{array}{l}0.62 \\
0.81\end{array}$ & $\begin{array}{l}0.80 \\
0.68\end{array}$ & $\begin{array}{l}1.14 \\
1.64\end{array}$ & $\begin{array}{l}0.85 \\
1.19\end{array}$ & $\begin{array}{l}0.05 \\
0.23\end{array}$ & $\begin{array}{c}<0.001 \\
0.36\end{array}$ & $\begin{array}{l}0.76 \\
0.82\end{array}$ & $\begin{array}{l}0.9 \\
1.7\end{array}$ \\
\hline
\end{tabular}


Table 3. Cont.

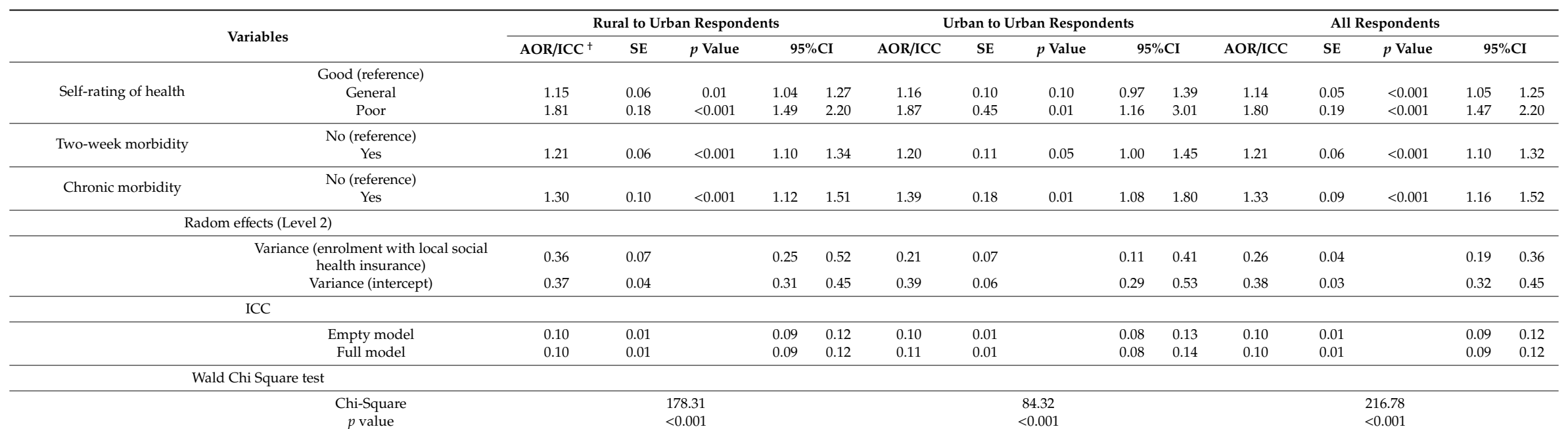

Note: * Average marginal effects (AME) of location of social health insurance funds: $4.8 \%$ (1.8\%, $7.7 \%)$ for rural-to-urban respondents; $1.9 \%$ (-1.8\%, 5.6\%) for urban-to-urban respondents; $3.5 \%(1.3 \%, 5.8 \%)$ for all respondents. ${ }^{\dagger}$ ICC: intraclass correlation coefficient; AOR: adjusted odds ratio; SE: standard error; CI: confidence interval. 
The contextual variable "county/district" contributed to $10 \%$ of the total variance of the dependent variable (visits to physicians): $10 \%$ for the rural-to-urban migrants and $11 \%$ for the urban-to-urban migrants (Table 3). The regression models also revealed that female migrants were more likely to visit a physician when they felt ill or were injured compared with their male counterparts (AOR $=1.08$, $p=0.01$ ). Those who were covered by the BMIUE were less likely to visit a medical doctor than those covered by the BMIUR/RNCMS (AOR $=0.85, p<0.001$ ). The respondents experiencing health problems, such as those who worse self-rated health (AOR $=1.14-1.80, p<0.001$ ), reported two-week morbidity ( $\mathrm{AOR}=1.21, p<0.001)$, and had chronic morbidity ( $\mathrm{AOR}=1.33, p<0.001$ ) were more likely to visit physicians when needed. These effects were consistent between the rural-to-urban and the urban-to-urban migrants, despite a lack of statistical significance in the gender effect (AOR $=1.06$, $p=0.10$ ) for the rural-to-urban migrants and the effect of type of insurance (AOR $=0.95, p=0.62$ ) for the urban-to-urban migrants (Table 3).

The interaction effect between location and type of health insurance on visits to physicians was statistically significant (Supplementary File Tables S3 and S4). The location effect was higher on visits to physicians in those covered by the BMIUE in comparison with those covered by the merged insurance BMIUR/RNCMS, but only statistically significant in the rural-to-urban migrants (AOR $=1.54, p=0.01$, Table S3).

\section{Discussion}

This study provides some new insight into the outcomes of the new health insurance arrangements in China that aim at improving health services for internal migrants. The results show that there still exist gaps in the use of health services, both in medical treatments and in preventive care, between the internal migrants with and without local health insurance coverage one year after the implementation of the nationwide on-the-spot medical bill settlement system. The internal migrants covered by a health insurance program outside of their residential location tend to use less healthcare services. Such a disparity varies by the type of insurance and between the rural-to-urban and the urban-to-urban migrants. The contextual variable "county/district" contributes to $44 \%$ of the variance of the establishment of health records and $10 \%$ of the variance of visiting to physicians when needed, although household income was not identified as a significant predictor of visits to physicians.

The inequality in use of health services deserves further policy attention. Our data show that the overall level of health services used by the internal migrants is low: only about half of the internal migrants visited a medical doctor when needed, compared with a national average of $84.5 \%$ (in 2013) [69]. The low coverage (31.28\%) of health records in this population is particularly concerning because it is unlikely that these migrants are able to obtain access to the essential public health services (such as case management of chronic conditions) outside of one's residential location [69-71]. On average, almost $70 \%$ of the entire population in China had been covered by a health record in 2013 [69]. The inequality in health services may further exacerbate the existing gaps in health and health risks between internal migrants and the locals. This has been considered as a serious risk amid the recent outbreak of COVID-19. Rural-to-urban migrants are usually exposed to high risks of infectious diseases [72]. The hesitation of internal migrants in seeking local medical attention could seriously jeopardize the public health efforts to contain the spread of infectious diseases [72,73]. To address this problem, the Chinese government has made testing and hospital services free of charge to everybody during the COVID-19 crisis [74] through subsidizing the insurance funds [75]. However, it is imperative to prepare for future challenges by tackling the fundamental shortfalls of the social health insurance arrangements.

The on-the-spot settlement system of medical bills appears to have not yet achieved its full potential. This study shows that the inequality in use of health services between the migrants with and without local insurance coverage still existed one year after the introduction of the system. The internal migrants without local health insurance coverage used significantly less healthcare services. This may be caused by the existence of thousands of social health insurance funds and a lack of coordination 
and coherent policies in China [27]. Although a nationwide network has been established to facilitate on-the-spot settlements of medical bills across regions, great barriers exist for the internal migrants to take advantage of the new arrangements. Some researchers call for expansion of the limited number of hospitals assigned by the national health insurance authority for the on-the-spot medical bill settlements [48,76]. The restriction of the on-the-spot medical bill settlements to hospital admissions for acute illness is also attracting increasing criticisms. For services other than acute hospital admissions, patients have to pay out of pocket before asking for a proportion of reimbursements from their enrolled fund. In addition, many internal migrants are not even aware of the relevant policies and procedures, let alone how to navigate through the complex processes [40]. However, the gaps appear to have decreased in comparison with the findings reported in a previous study [39]. We found a gap of 3.5 percentage points (adjusted for variations in the control variables) in use of medical services between the migrants with and without local insurance coverage, much smaller than the 7.4 percentage point gap reported prior to the introduction of the on-the-spot bill settlement system.

It is worth noting that the association between local health insurance enrolment and use of health services is stronger in the rural-to-urban migrants than in the urban-to-urban migrants. The gap in visiting physicians when needed between the urban-to-urban migrants with and without local insurance coverage has virtually closed one year after the introduction of the system. China has a long history of dual welfare systems. Urban residents are entitled to higher levels of welfare and income compared to their rural counterparts. This makes rural-to-urban migrants particularly vulnerable to insurance arrangements: they are more likely to abandon health services due to financial barriers arising from the failure of the on-the-spot medical bill settlements [38]. Although the BMIUE programs are often more generous and can cover medical services outside of the fund location [26,41,42,77], very few rural-to-urban migrants are allowed to enroll with the BMIUE. This may jeopardize the potential effect of the local insurance enrolment policy on use of health services $[38,77,78]$.

In theory, the merging of the BMIUR and the RNCMS may be able to mitigate some of the consequences of the mismatch between insurance fund location and provision of health services. This may be true for medical services for illness treatments. However, this study shows that the location effect was lower on the establishment of health records in those covered by the BMIUE in comparison with those covered by the merged insurance BMIUR/RNCMS. Clearly, preventive care has not been targeted by the merging of the two insurance programs. Unlike medical services, access to health records is less likely to be influenced by insurance arrangements directly. While the BMIUE enrollees may be able to enjoy public health services offered by their employers, the only way for the BMIUR and RNCMS enrollees to receive public health services is through their local primary care facilities. Unfortunately, the rural-to-urban migrants who hold a rural household registration may not be seen as urban "locals" even if the BMIUR and RNCMS programs are merged.

The findings of this study have some policy implications for China's health insurance development. Neither local enrollment of social health insurance nor on-the-spot settlements of medical bills would offer a perfect solution to the inequality problems in use of health services by internal migrants in China. Low coverage $(<25 \%)$ of local health insurance in internal migrants is evident, defying the policy encouragement of the Chinese government [44-46]. The existence of numerous health insurance funds has created a significant challenge to the portability arrangement of insurance funds, in particular between urban and rural. However, it is important to note that the migrants who endorse themselves as locals (as evidenced by joining local insurance) are more likely to have a health record and consequently receive local public health services and medical services despite the absence of a direct link between insurance arrangements and health records. This study revealed a greater gap in registration with public health services compared with that in medical services between those with and without local insurance coverage. Fund location has a greater association with use of health services in the rural-to-urban migrants compared with that in the urban-to-urban migrants.

In recent years, there has been an increasing call for further consolidation of the existing health insurance funds both vertically and horizontally at a higher administrative level [26,41]. Although 
consolidation of health insurance funds may offer a fundamental solution to the problems in health services experienced by internal immigrants [41], some transitional strategies need to be developed urgently in line with their diverse needs [25]. For example, local enrollments in the BMIUE can be made compulsory for those who have an employment contract, while others can be encouraged to enroll with local BMIUR. Local enrollments can also be encouraged through easier and fairer fund transfer arrangements. Meanwhile, a cross-regional fund can be established to simplify on-the-spot settlements of medical bills and extend its coverage beyond hospital admissions for acute illness [47]. Such arrangements are particularly important for the rural-to-urban migrants who change jobs and residential locations frequently and find it hard to enroll in an insurance scheme locally. However, this will require a coordinated risk sharing mechanism across funds with varied levels of premium and entitlement policies [52]. In addition, it is important for the public to participate in policy dialogues and contribute to the development of more appropriate insurance arrangements tailored to the diverse needs of the internal migrants.

This study provides a comprehensive assessment on inequalities in healthcare services within the internal migrant populations and in comparison with the average of the entire population in China. It highlights the importance of including preventive care in inequality studies. Healthcare seeking behaviors can be shaped by many factors, including the inherent link between preventive care and illness treatments. A better alignment between health insurance policies and public health activities should be advocated. This will require a whole-of-government approach to welfare system development.

There are several limitations in this study. Due to unavailability of data, only self-reported health status was included in risk-adjustment of the findings. We were not able to decompose the outcome indicators into more specific health services. Medical expenses were not analyzed either. The study adopted a cross-sectional design, no causal relationships should be assumed. We cannot rule out the possible influence of selection bias on the effect of local health insurance: those who intend to use more services may be more likely to enroll with a local insurance scheme. Further studies are needed to investigate how on-the-spot settlements of medical bills are implemented through coordination across multiple insurance funds.

\section{Conclusions}

In conclusion, although on-the-spot settlements of medical bills have been encouraged by the Chinese government, inequalities in the use of both medical and public health services still exist among internal migrants with and without local social health insurance coverage. Higher levels of use of medical and public health services are associated with local health insurance coverage. The impact of local insurance enrollments is greater in the rural-to-urban migrants compared with the urban-to-urban migrants, especially for the use of medical services. Meanwhile, the effects of local insurance enrollments also vary with the type of insurance. The low coverage of health records in internal migrants is particularly concerning because it may further exacerbate the existing gaps in health and health risks between internal migrants and the local population. Further studies are needed to investigate how on-the-spot settlements of medical bills are implemented through coordination across multiple insurance funds and how public health services can be improved for internal migrants.

Supplementary Materials: The following are available online at http://www.mdpi.com/1660-4601/17/17/6327/s1, Table S1. Interaction effect of location and type of social health insurance on the establishment of personal health records: results of two-level logistic regression models. Table S2. Interaction effect of location and type of social health insurance on the establishment of personal health records: results of two-level logistic regression models. Table S3. Interaction effect between location and type of social health insurance on visits to local physicians when needed: results of two-level logistic regression models. Table S4. Interaction effect between location and type of social health insurance on visits to local physicians when needed: results of two-level logistic regression models.

Author Contributions: Conceptualization, Q.Y., C.L. and J.S.; Data curation, J.S.; Formal analysis, Q.Y.; Funding acquisition, Q.Y. and J.S.; Methodology, Q.Y. and C.L.; Writing—original draft, Q.Y.; Writing—review and editing, C.L. All authors have read and approved of the final version of the manuscript. 
Funding: This research was funded by the National Natural Science Foundation of China (71603188), the Open Foundation from the Health Commission of China (NHC) Key Laboratory of Health Technology Assessment (Fudan University) (FHTA2019-01), the National Social Science Foundation of China (16BGL150) and the Fundamental Research Funds for the Central Universities. The China Scholarship Council (CSC) provided visiting fellowship support (No. 201806275011) to Qiang Yao while he conducted part of the study at La Trobe University. The funding bodies have no role in the design of the study, collection, analysis, and interpretation of data, and writing and preparation of the manuscript.

Acknowledgments: The authors thank the Migrant Population Service Center, National Health Commission of China for providing data support. We would like to thank all of the participants in the CMDS.

Conflicts of Interest: The authors declare no conflict of interest.

Availability of Data and Materials: The datasets used in this study are not publicly available due to restrictions imposed on this study, but they are available from the Migrant Population Service Center, National Health Commission of China upon reasonable requests.

Ethics Approval and Consent to Participate: As this study was a secondary analysis of de-identified data collected by the government, ethics approval has been exempted. The 2017 China Migrants Dynamic Survey was approved by the China National Bureau of Statistics [No. NBS (2015)72], and written informed consent was obtained from all participants at the time of data collection. Use of the data for this study was approved by the Migrant Population Service Center, National Health Commission of China. All procedures performed in this study were in accordance with the ethical standards of the research committee of Institute of Health, Wuhan University and with the 1975 Helsinki declaration and its later amendments or comparable ethical standards.

\section{References}

1. Peng, B.; Ling, L. Association between rural-to-urban migrants's social medical insurance, social integration and their medical return in China: A nationally representative cross-sectional data analysis. BMC Public Health 2019, 19, 86. [CrossRef] [PubMed]

2. Wang, Q. Health of the elderly migration population in China: Benefit from individual and local socioeconomic status? Int. J. Environ. Res. Public Health 2017, 14, 370. [CrossRef] [PubMed]

3. Cai, F. Hukou system reform and unification of rural-urban social welfare. China World Econ. 2011, 19, 33-48. [CrossRef]

4. Song, Y. What should economists know about the current Chinese hukou system? China Econ. Rev. 2014, 29, 200-212. [CrossRef]

5. Jan, C.; Zhou, X.; Stafford, R.S. Improving the health and well-being of children of migrant workers. Bull. World Health Organ. 2017, 95, 850. [CrossRef]

6. Shao, C.; Meng, X.; Cui, S.; Wang, J.; Li, C. Income-related health inequality of migrant workers in China and its decomposition: An analysis based on the 2012 China labor-force dynamics survey data. J. Chin. Med. Assoc. 2016, 79, 531-537. [CrossRef]

7. Ji, Y.; Liu, S.; Zhao, X.; Jiang, Y.; Zeng, Q.; Chang, C. Smoking and its determinants in Chinese internal migrants: Nationally representative cross-sectional data analyses. Nicotine Tob. Res. 2016, 18, 1719-1726. [CrossRef]

8. Zong, Z.; Huang, J.; Sun, X.; Mao, J.; Shu, X.; Hearst, N. Prenatal care among rural to urban migrant women in China. BMC Pregnancy Childbirth 2018, 18, 301. [CrossRef]

9. Zhu, Y.F.; Hu, X.R.; Yang, B.; Wu, G.W.; Wang, Z.; Xue, Z.M.; Shi, J.C.; Ouyang, X.; Liu, Z.N.; Rosenheck, R. Association between migrant worker experience, limitations on insurance coverage, and hospitalization for schizophrenia in Hunan Province, China. Schizophr. Res. 2018, 197, 93-97. [CrossRef]

10. Zhang, J.; Lin, S.; Liang, D.; Qian, Y.; Zhang, D.; Hou, Z. Public health services utilization and its determinants among internal migrants in China: Evidence from a nationally representative survey. Int. J. Environ. Res. Public Health 2017, 14, 1002. [CrossRef]

11. Zheng, L.; Hu, R.; Dong, Z.; Hao, Y. Comparing the needs and utilization of health services between urban residents and rural-to-urban migrants in China from 2012 to 2016. BMC Health Serv. Res. 2018, $18,717$. [CrossRef] [PubMed]

12. National Health Commission of P.R. China. Report on China's Migrants Population Development; China Population Publishing House: Beijing, China, 2018. 
13. Li, C.-C.; Meng, X.-H.; Wang, J.-R.; Ma, H.-J.; Chen, C.; Liu, Y.-Q. Association between sociodemographic, psychosocial, lifestyle factors, and self-reported health among migrant laborers in China. J. Chin. Med. Assoc. 2017, 80, 204-211. [CrossRef] [PubMed]

14. Meng, Y.; Han, J.; Qin, S. The impact of health insurance policy on the health of the senior floating population-Evidence from China. Int. J. Environ. Res. Public Health 2018, 15, 2159. [CrossRef] [PubMed]

15. Zheng, Y.; Ji, Y.; Dong, H.; Chang, C. The prevalence of smoking, second-hand smoke exposure, and knowledge of the health hazards of smoking among internal migrants in 12 provinces in China: A cross-sectional analysis. BMC Public Health 2018, 18, 655. [CrossRef] [PubMed]

16. Niu, G.; Zhao, G. Living condition among China's rural-urban migrants: Recent dynamics and the inland-coastal differential. Hous. Stud. 2018, 33, 476-493. [CrossRef]

17. Lu, L.; Zeng, J.; Zeng, Z. What limits the utilization of health services among China labor force? Analysis of inequalities in demographic, socio-economic and health status. Int. J. Equity Health 2017, 16, 30. [CrossRef]

18. Baeten, S.; Van Ourti, T.; Van Doorslaer, E. Rising inequalities in income and health in China: Who is left behind? J. Health Econ. 2013, 32, 1214-1229. [CrossRef]

19. Zheng, Y.; Chang, C.; Ji, Y.; Yuan, Y.; Jiang, Y.; Li, Z. The status quo and subjective need for health knowledge among internal migrants. Chin. J. Health Educ. 2017, 33, 3.

20. Mou, J.; Cheng, J.; Griffiths, S.M.; Wong, S.Y.; Hillier, S.; Zhang, D. Internal migration and depressive symptoms among migrant factory workers in Shenzhen, China. J. Community Psychol. 2011, 39, $212-230$. [CrossRef]

21. Niu, J.; Zheng, Z.; Zhang, L.; Zeng, X. Labor migrants' working and living environments and the related health impacts-evidences from Shenzhen. Popul. Res. 2011, 35, 64-75.

22. He, H.; Cao, G.; Shen, H.; Xie, S. Empirical study on the effect of health migration: Trend and influencing factors of health status of young migrants. Chin. J. Health Policy 2018, 11, 1-9.

23. Zhang, X.; Yu, B.; He, T.; Wang, P. Status and determinants of health services utilization among elderly migrants in China. Glob. Health Res. Policy 2018, 3, 8. [CrossRef] [PubMed]

24. Yip, W.C.-M.; Hsiao, W.C.; Chen, W.; Hu, S.; Ma, J.; Maynard, A. Early appraisal of China's huge and complex health-care reforms. Lancet 2012, 379, 833-842. [CrossRef]

25. Huang, Z.Y.; Pan, Z.H. Improving migrants' access to the public health insurance system in China: A conceptual classification framework. Asian Pac. Migr. J. 2017, 26, 274-284. [CrossRef]

26. Meng, Q.; Fang, H.; Liu, X.; Yuan, B.; Xu, J. Consolidating the social health insurance schemes in China: Towards an equitable and efficient health system. Lancet 2015, 386, 1484-1492. [CrossRef]

27. Huang, Y.; Guo, F. Welfare programme participation and the wellbeing of non-local rural migrants in metropolitan China: A social exclusion perspective. Soc. Indic. Res. 2017, 132, 63-85. [CrossRef]

28. Zhou, Q.; Liu, G. Differences on benefiting from medicare by household registration: A study based on local registered population and floating population. Nankai Econ. Stud. 2016, 32, 77-94.

29. Mou, J.; Griffiths, S.M.; Fong, H.; Dawes, M.G. Health of China's rural-urban migrants and their families: A review of literature from 2000 to 2012. Br. Med. Bull. 2013, 106, 19-43. [CrossRef]

30. Song, X.L.; Zou, G.Y.; Chen, W.; Han, S.Q.; Zou, X.; Ling, L. Health service utilisation of rural-to-urban migrants in Guangzhou, China: Does employment status matter? Trop. Med. Int. Health 2017, 22, 82-91. [CrossRef]

31. Fan, X. The health status, problems and countermeasures of floating population. Macroecon. Manag. 2019, 35, 42-47.

32. Jing, Z.; Wang, Y.; Ding, L.; Tang, X.; Feng, Y.; Zhou, C. Effect of social integration on the establishment of health records among elderly migrants in China: A nationwide cross-sectional study. BMJ Open 2019, 9, e034255. [CrossRef] [PubMed]

33. Guo, J.; Shao, F.; Fan, H.; Xue, L.; Wu, Y. Analysis on the access to the basic public health care services and influencing factors among migrants. Chin. J. Health Policy 2016, 9, 75-82.

34. Du, B.; Cao, G.; Xu, F. Analysis on health status and medical service utilization among the migrant elderly in China. Chin. J. Health Policy 2018, 11, 10-16.

35. Guo, J.; Dai, Y.; Fu, L.; Yang, H.; Liu, L. Structural equation model of the influencing factors of the medical behavior of floating elderly population. Chin. J. Health Policy 2019, 12, 35-40. 
36. Cai, X.; Yang, F.; Bian, Y. Gap analysis on hospitalized health service utilization in floating population covered by different medical insurances: Case study from Jiangsu Province, China. Int. J. Equity Health 2019, 18, 1-10. [CrossRef]

37. Chen, W.; Zhang, Q.; Renzaho, A.M.; Zhou, F.; Zhang, H.; Ling, L. Social health insurance coverage and financial protection among rural-to-urban internal migrants in China: Evidence from a nationally representative cross-sectional study. BMJ Glob. Health 2017, 2, e000477. [CrossRef] [PubMed]

38. Jiang, H. Research on Medical insurance and medical service utilization status of floating population-Based on national mobile population dynamic monitoring data. World Surv. Res. 2016, 24, 14-20.

39. Han, J.; Meng, Y. Institutional differences and geographical disparity: The impact of medical insurance on the equity of health services utilization by the floating elderly population-evidence from China. Int. J. Equity Health 2019, 18, 91. [CrossRef]

40. Zhang, J.; Ni, B.; Ji, Y.; Chang, C.; Wang, Y. Health status and the utilization of basic public health service of the Chinese elderly floating population. Mod. Prev. Med. 2017, 44, 3526-3530.

41. He, A.J.; Wu, S. Towards universal health coverage via social health insurance in China: Systemic fragmentation, reform imperatives, and policy alternatives. Appl. Health Econ. Health Policy 2017, 15, 707-716. [CrossRef]

42. Liu, G.G.; Vortherms, S.A.; Hong, X. China's health reform update. Annu. Rev. Public Health 2017, 38, 431-448. [CrossRef]

43. Notice of the General Office of the Ministry of Human Resources and Social Security on the procedures of transfer and succession of basic medical insurance for internal migrant workers. Shandong Hum. Resour. Soc. Secur. 2016, 25, 61-62.

44. Ministry of Human Resources and Social Security of the People's Republic of China. InterimMeasures on the Transfer of Continuation of Basic Pension for Urban Enterprise Employees. Available online: http: //www.mohrss.gov.cn/SYrlzyhshbzb/shehuibaozhang/zcwj/yiliao/200912/t20091231_86861.html (accessed on 6 August 2019).

45. Ministry of Human Resources and Social Security of the People's Republic of China. Measures for Farmers to Settle in the City to Participate in Basic Medical Insurance and Relationship Transfer and Follow-Up Work. Available online: http://www.mohrss.gov.cn/SYrlzyhshbzb/shehuibaozhang/zcwj/yiliao/201509/t20150911_ 220299.html (accessed on 6 August 2019).

46. Ministry of Human Resources and Social Security of the People's Republic of China. Procedures for the Transfer of the Basic Medical Insurance Relationship of Migrants Workers. Available online: http: //www.mohrss.gov.cn/SYrlzyhshbzb/shehuibaozhang/zcwj/yiliao/201606/t20160630_242630.html (accessed on 6 August 2019).

47. Liu, L. Medical treatment in different places for the elderly floating population: Behavioral characteristics, support system and institutional guarantee. Popul. Soc. 2019, 35, 7.

48. Xie, L.; Chen, Q.; Hu, H. Research progress for remote medical treatment of basic medical insurance in China. Chin. Hosp. Manag. 2018, 38, 13.

49. Zheng, B. 30 Years of reform and openness in China: Development and challenges of social security system for floating population. Chin. J. Popul. Sci. 2008, 5, 2-17.

50. Cheng, Z.M.; Nielsen, I.; Smyth, R. Access to social insurance in urban China: A comparative study of rural-urban and urban-urban migrants in Beijing. Habitat Int. 2014, 41, 243-252. [CrossRef]

51. Zhao, D.H.; Rao, K.Q.; Zhang, Z.R. Coverage and utilization of the health insurance among migrant workers in Shanghai, China. Chin. Med. J. 2011, 124, 2328-2334. [CrossRef]

52. He, Q.; Lv, P.; Wang, Y.; Chen, S.; Li, J. Current situation and suggestions for instant settlement of off-site medical treatment from the perspective of public hospitals. Mod. Hosp. Manag. 2019, 17, 34-36.

53. Ministry of Human Resources and Social Security of the People's Republic of China. Notice on Enabling on-the-Spot Settlements of Medical Bills for Across-Provincial Medical Treatment. Available online: http://www.mohrss.gov.cn/SYrlzyhshbzb/shehuibaozhang/zcwj/201612/t20161215_262040.html (accessed on 5 August 2020).

54. Ministry of Human Resources and Social Security of the People's Republic of China. Guiding on Enabling on-the-Spot Settlements of Medical Bills Outside of Insurance Fund Location for Basic Medical Insurance. Available online: http://www.mohrss.gov.cn/SYrlzyhshbzb/ldbk/shehuibaozhang/yiliao/201412/t20141224_ 147142.htm (accessed on 5 August 2020). 
55. He, Y.; Hou, Z. Effects of basic health insurance ecdemic settlement policy on health services utilization. Chin. J. Health Policy 2016, 9, 67-71.

56. Huang, C.; Liu, C.-J.; Pan, X.-F.; Liu, X.; Li, N.-X. Correlates of unequal access to preventive care in China: A multilevel analysis of national data from the 2011 China Health and Nutrition Survey. BMC Health Serv. Res. 2016, 16, 177. [CrossRef]

57. Ma, S.; Zhou, X.D.; Jiang, M.M.; Li, Q.J.; Gao, C.; Cao, W.M.; Li, L. Comparison of access to health services among urban-to-urban and rural-to-urban older migrants, and urban and rural older permanent residents in Zhejiang Province, China: A cross-sectional survey. BMC Geriatr. 2018, 18. [CrossRef] [PubMed]

58. Zhao, Y.; Ni, Q.; Zhou, R. What factors influence the mobile health service adoption? A meta-analysis and the moderating role of age. Int. J. Inf. Manag. 2018, 43, 342-350. [CrossRef]

59. National Health Commission of P.R. China. Handbook of China Migrants Dynamic Survey 2017. Available online: http://www.chinaldrk.org.cn/wjw/file/data/2009_2017.rar (accessed on 28 August 2020).

60. Kim, H.-K.; Lee, M. Factors associated with health services utilization between the years 2010 and 2012 in Korea: Using Andersen's behavioral model. Osong Public Health Res. Perspect. 2016, 7, 18-25. [CrossRef] [PubMed]

61. Li, Y.-N.; Nong, D.-X.; Wei, B.; Feng, Q.-M.; Luo, H.-Y. The impact of predisposing, enabling, and need factors in utilization of health services among rural residents in Guangxi, China. BMC Health Serv. Res. 2016, 16, 592. [CrossRef] [PubMed]

62. Babitsch, B.; Gohl, D.; von Lengerke, T. Re-revisiting Andersen's Behavioral Model of Health Services Use: A systematic review of studies from 1998-2011. GMS Psycho Soc. Med. 2012, 9. [CrossRef]

63. Peng, Y.C.; Chang, W.H.; Zhou, H.Q.; Hu, H.P.; Liang, W.N. Factors associated with health-seeking behavior among migrant workers in Beijing, China. BMC Health Serv. Res. 2010, 10, 69. [CrossRef]

64. Pourat, N.; Andersen, R.M.; Marcus, M. Assessing the contribution of the dental care delivery system to oral health care disparities. J. Public Health Dent. 2015, 75, 1-9. [CrossRef]

65. Andersen, R.M.; Davidson, P.L.; Baumeister, S.E. Improving access to care in America. In Changing the U.S. Health Care System: Key Issues in Health Services Policy and Management, 3rd ed.; Jossey-Bass: San Francisco, CA, USA, 2007; pp. 3-31.

66. Larsen, K.; Merlo, J. Appropriate assessment of neighborhood effects on individual health: Integrating random and fixed effects in multilevel logistic regression. Am. J. Epidemiol. 2005, 161, 81-88. [CrossRef]

67. Wang, Y.; Fan, Y.; Wang, X.; Ma, Y.; Wu, C.; Shi, H.; Han, H.; Liu, W.; Liu, C. Multilevel analysis of individual, organizational, and regional factors associated with patient safety culture: A cross-sectional study of maternal and child health institutions in China. J. Patient Saf. 2019. [CrossRef]

68. Zhang, Y.; Zhou, Z.; Gao, J.; Wang, D.; Zhang, Q.; Zhou, Z.; Su, M.; Li, D. Health-related quality of life and its influencing factors for patients with hypertension: Evidence from the urban and rural areas of Shaanxi Province, China. BMC Health Serv. Res. 2016, 16, 277. [CrossRef]

69. Center for Health Statistics and Information, Ministry of Health China. An Analysis Report of National Health Services Survey in China, 2013; Center for Health Statistics and Information, Ministry of Health China: Beijing, China, 2015.

70. Zhang, P.; Zhang, L.; Wang, F.; Cheng, Y.; Liang, Y. Societal and individual determinants in the enrollment of personal health records: A preliminary investigation from C hina. Int. J. Health Plann. Manag. 2019, 34, e752-e762. [CrossRef] [PubMed]

71. Su, L.; Sun, L.; Xu, L. Review on the prevalence, risk factors and disease management of hypertension among floating population in China during 1990-2016. Glob. Health Res. Policy 2018, 3, 1-8. [CrossRef] [PubMed]

72. Fan, C.; Cai, T.; Gai, Z.; Wu, Y. The relationship between the migrant population's migration network and the risk of COVID-19 transmission in China-empirical analysis and prediction in prefecture-level cities. Int. J. Environ. Res. Public Health 2020, 17, 2630. [CrossRef] [PubMed]

73. Chen, S.; Yang, J.; Yang, W.; Wang, C.; Bärnighausen, T. COVID-19 control in China during mass population movements at New Year. Lancet 2020, 395, 764-766. [CrossRef]

74. National Healthcare Security Administration P.R. China; Ministry of Finance of P.R. China. Notice on Medical Insurance for Pneumonia Epidemic with COVID-19. Available online: http://www.nhsa.gov.cn/art/ 2020/1/23/art_37_2284.html (accessed on 17 April 2020).

75. Wang, J.; Wang, Z. Strengths, Weaknesses, Opportunities and Threats (SWOT) analysis of China's prevention and control strategy for the COVID-19 epidemic. Int. J. Environ. Res. Public Health 2020, 17, 2235. [CrossRef] 
76. Li, K. Report on the Work of the Government. Available online: http://english.gov.cn/premier/speeches/2019/ 03/16/content_281476565265580.htm (accessed on 3 July 2019).

77. Qian, Z.; Lin, S.; Hou, Z. Significantly improving local hospitalization rate of migrants under urban basic medical insurance: Based on the evidence of national migrant dynamic supervision survey. Chin. Health Econ. 2016, 35, 44-46.

78. Wang, H.Q.; Zhang, D.L.; Hou, Z.Y.; Yan, F.; Hou, Z.Y. Association between social health insurance and choice of hospitals among internal migrants in China: A national cross-sectional study. BMJ Open 2018, 8, e018440. [CrossRef]

(C) 2020 by the authors. Licensee MDPI, Basel, Switzerland. This article is an open access article distributed under the terms and conditions of the Creative Commons Attribution (CC BY) license (http://creativecommons.org/licenses/by/4.0/). 